\title{
Moral Commitments to Community: Mapping Social Responsibility and its Ambiguities Among Small Business Owners
}

\author{
Submitted by: \\ Tara J. Fenwick \\ Professor and Head of Department, Educational Studies \\ University of British Columbia \\ and Elizabeth A. Lange \\ Assistant Professor, Educational Policy Studies \\ University of Alberta
}

\section{Abstract}

This article maps the different moral positions related to social responsibility (SR) as articulated by 25 small business owners and explains how they understand their positions within a range of SR practices. The morality underpinning their social responsibility tended to be embedded in a sense of relationship with and commitment to the well-being of the local geographic community but was threaded with felt ambiguities. Through an ethical analysis, we argue that this moral commitment to community is connected to a relational worldview, distinct from values and assumptions driving the existing economic system, yet they pursue this vision as individual actors rather than working collectively.

Keywords: corporate social responsibility, small business, ethics and business, sustainability and business

\section{Introduction}

Along with the rise of corporate social responsibility (CSR) discourse and practice, there has been a concurrent rise in studies exploring how ethics and morality are understood by business owners and consequently how they practice social responsibility. Particularly understudied have been the concepts of social responsibility that small or micro business owners operationalize. This article explicates the findings from a qualitative study involving 25 small business owners who practice social responsibility in various sectors located in western Canada. Our findings 
confirm the findings from a number of European studies on small and medium-sized socially responsible enterprises (SMEs), but this study is unique by revealing that the morality underpinning social responsibility practices by small business owners tends to be embedded in a sense of relationship with and commitment to the well-being of the local geographic community. Yet, the precise nature of this commitment and its enactment in business decision-making and practices appears to vary according to the nature of the business, the owners' meanings about community and thus nature and extent of business responsibility, about viability (what is possible to do), and about the owners' personal connection with and interests in the community. Further, this moral commitment is threaded with felt ambiguities, such as the ambiguity around the business owner's role as a social change agent in the community, and the extent to which community demands should take precedence in business decision-making. Motives and incentives for making moral commitments to community can come into conflict with the demands of operating a profit-making enterprise, and tensions can emerge around extent of interconnection with community while retaining the independence and distance required for competitiveness. This article maps the different moral positions related to social responsibility (SR) as articulated by the 25 small business owners and explains their positions within a range of SR practices. Through an ethical analysis, we argue that this moral commitment to community is connected to a relational worldview that they perceive to be distinct from values and assumptions driving the existing economic system, yet they pursue this vision as individual actors rather than working collectively. 


\section{Corporate Social Responsibility and Small Business}

Corporate social responsibility (CSR) can be defined as a commitment by business to respond ethically to social and/or ecological concerns, often by recognizing a "triple bottom line" of investing shareholders, the natural environment, and non-shareholding stakeholders including local community, government, customers, employees, and interest groups ranging from environmental to religious, ethnic, and trade groups (CBSR, 2001). In actuality, corporate social responsibility is not a unitary phenomenon but is characterized by wide-ranging meanings and practices including transparent accountability, respect for ethical values, commitment to improving quality of life and preserving natural environments, and support for local community (Hopkins, 2003; Crowther and Rayman-Bacchus, 2004; CBSR, 2001).

In Canada where this study was conducted, corporate SR is described as an "urgent social and political issue" in the federally-sponsored National Corporate Social Responsibility project (Conference Board of Canada, 2004). However, business ethical commitments and motives to participate in CSR range widely, from strategic to altruistic (Husted and de Jesus Salazar, 2006; McWilliams et al., 2006). Some firms perceive CSR to be simply new language for old business commitments to philanthropy and being good citizens (Joyner \& Payne, 2002; Whitehouse, 2006). Others argue that a corporation's defining and sole ethical responsibility is to create profits for shareholders (Hinkley, 2002) and that a CSR agenda is a vague altruistic project that does not serve shareholder interests or, therefore, the public good (Husted and de Jesus Salazar, 2006). Some firms treat CSR as a public relations exercise, promoting ethical suspicions of 'greenwashing' to camouflage resistance to systemic change (Dobbin, 1998).

Ethical demands of diverse stakeholders pose conflicting definitions of the 'good' for business: fiduciary responsibility to company shareholders, utilitarian demands to provide greatest benefits to the greatest number, virtue demands to behave as a 'good' corporate citizen in a particular context, duty demands to enact ethical principles (honesty, justice, respect), and transactional demands to compensate local communities fairly for the corporate footprint and economic gain. CSR doctrines have yet to articulate approaches to classifying, prioritizing and understanding these diverse stakeholder needs on the one hand, and the extent of corporate responsibility to them on the other (Coelho, McClure, \& Spry, 2003). Internally, levels of ethical commitment to CSR principles range widely within companies (Hemingway and McLagan, 2004; McWilliams et al., 2006). Employee resistance is a particular problem facing some managers interested in CSR (L'Etang, 1995). The public also can be ethically unpredictable, ultimately choosing lower prices over responsible products despite their demands for corporate social responsibility (Davidson and Hatt, 2005).

CSR commitments are particularly challenging for small businesses that often cope with slim resources, loan recall vulnerability, constant work overload in everyday operations, and networked structures of production. The larger the firm's size the more cash is donated to philanthropy (Seifert, Morris and Bartkus, 2003) and the greater the tendency to develop specific, formal CSR strategies to focus on particular stakeholder needs (Perrini et al., 2007). In this large survey of Italian businesses, Perrini and colleagues found that small businesses tend to feel greatest responsibility to their customers. In fact, small businesses experience most of their ethical conflicts in relation to their clients, and mostly with regard to contracts and agreements (Vitell et 
al., 2000). Lepoutre and Heene (2006) concurred that constraints related to the small business do affect CSR commitments. However, they indicate that the unique characteristics of these conditions - including personal, contextual and issue characteristics - create a more nuanced effect than simple barriers, and that small business can overcome these constraints. Jenkins (2006) suggests that because SMEs on the whole learn mostly through networking with peers, that this activity represents an opportunity to strengthen CSR if sufficiently strong leaders will champion such networks.

One ethical issue that we have found in previous studies among some small business owners, particularly women in micro-enterprise, is a desire to change certain measures of success and taken-for-granted business structures such as traditional business planning (Co-author, 2002a).

Competitive structures of growth and profit were challenged by these business owners in favour of a conscious stance to focus more on contributing to local communities and others' well-being, a stance that owners described as ethics-driven. Some, in fact, had started their business primarily as a way to create a space for work that was ethical: in their terms, this meant work that was creative, socially just, collaborative and community-oriented - but still viable as a business (Co-author, 2002b). The close connection of business, personal identity and values among small business owners is well documented. For those who feel personally drawn to acting for social change, including change to the fundamentals of capitalism (relatively open markets, competition, perpetual growth, and profit), the tug between such ethical commitments and necessary activities to sustain a small business are difficult to reconcile.

Overall, there is considerable ambiguity surrounding the diverse ethical positions and motives to practice CSR, alongside the difficulties of sustaining these ethical commitments as documented in both large and small organizations. Given this diversity, it is useful to understand more deeply how small businesses understand their ethical commitments to CSR, and what moral positions they take in their CSR approaches and decision-making.

\section{Methodology}

To trace the meanings and practices of social responsibility in-depth at a micro-level, this study was designed to be qualitative and interpretive in nature, examining the perspectives and experiences narrated by twenty-five small business owner-managers located in western Canada. The region is notable for its economic prosperity in recent years both in relation to the rest of Canada and to the USA, chiefly due to large petroleum reserves at a time of high world oil prices. In terms of CSR, the Canadian federal government has only recently (in late 2006) taken up an explicit agenda of environmentalism in response to public opinion. CSR has been promoted at national levels through non-governmental agencies such as the Conference Board of Canada (2004) and the Canadian Business for Social Responsibility (CBSR, 2001) but compliance has been completely voluntary with few government incentives or disincentives.

The 25 study participants were all owners of micro-enterprises ranging in size from 1 to 11 employees, and ranging in years-in-business from two to sixteen (see Table 1). Business sectors were mostly in retail, business services, personal services and food service, with one in manufacturing. About two-thirds were owned by women. Potential participants were identified through indexes maintained by agencies such as Canadian Business for Social Responsibility as well as through snowball methods of obtaining referrals. Our criteria were firms that had been 
operating successfully at least two years (demonstrating viability), and that explicitly professed a commitment in their core business purpose and processes to values directly related to social and/or environmental responsibility (e.g. on their website or other promotional material). These small business owners were invited to join group dialogues for the purpose of sharing strategies and discussing new approaches to practice CSR in small business in a modified action research process. Collaborative action research inquiry (Kemmis \& McTaggart, 2000) involved combining methods of group dialogue, personal interviews, and collaborative thematic analysis. This process was aligned with "action learning" (Kember, 2000; McGill \& Beaty, 1995) which is well-established in workplace learning studies (Revans, 1995). The objective of the researchers was to stimulate collaborative conversations, as Feldman (1999) suggests, that were inquiring, reflective, and hermeneutic as well as to open the possibility for a collaborative action project for enhancing their practice of social responsibility.

Two groups of business owners were formed, one in each of two separate provinces. Each group met face-to-face 5-6 times over a total period of almost two years. At these meetings, participants talked together about their meanings, challenges and strategies in developing practices of social and environmental responsibility while surviving as a small business. The two groups evolved differently as they decided their own group objectives and any collaborative activities. Individual in-depth semi-structured interviews were held with each participant at the end of the dialogue process.

The researchers worked together to facilitate the dialogue at these meetings and recorded all proceedings through audiotaping (later fully transcribed), flipcharts and detailed field notes. All individual interviews were audiotaped and fully transcribed. Interpretive content analysis of group meetings, individual interviews, researcher notes, and transcripts examined relations among the individual and collectively stated purposes, meanings, values and strategies of CSR. Subsequent comparative data analysis identified common themes, significant differences, and points of tension among the participants. The broad themes and contradictions discussed in this article were verified with the two groups. Trustworthiness in data analysis was also strengthened through the multiple data sources, member checks with individual interviewees, participant validation, an audit trail maintained by the researchers, and meetings among the researchers to critically compare our interpretive analyses and question each other's biases and influences on the meanings emerging in the inquiry process, as recommended by Lincoln \& Guba (2000).

Table 1: Demographic Information for Study Participants. (All names are pseudonyms.)

\begin{tabular}{l|l|l|l|l|l|l|}
\hline $\begin{array}{l}\text { Business } \\
\text { Pseudonym }\end{array}$ & $\begin{array}{l}\text { Owner(s)/ } \\
\text { Represent- } \\
\text { ative } \\
\text { Pseudonym }\end{array}$ & Type of Business & City & $\begin{array}{l}\text { Number of } \\
\text { Employees }\end{array}$ & $\begin{array}{l}\text { Gender } \\
\text { Year } \\
\text { in } \\
\text { Busi } \\
\text { ness }\end{array}$ \\
\hline Apex Equipment & Leslie & $\begin{array}{l}\text { Wilderness equipment } \\
\text { retail }\end{array}$ & Edmonton & $20+$ & Female & 35 \\
\hline $\begin{array}{l}\text { Aputik } \\
\text { Garments }\end{array}$ & Alasie & $\begin{array}{l}\text { Clothing design and } \\
\text { manufacture }\end{array}$ & Vancouver & 3 & Female & 2 \\
\hline Conscious & Leah & $\begin{array}{l}\text { Communications and } \\
\text { advertising }\end{array}$ & Vancouver & 8 & Female & 14 \\
\hline
\end{tabular}




\begin{tabular}{|c|c|c|c|c|c|c|}
\hline Creativity & & & & & & \\
\hline $\begin{array}{l}\text { Earth's Grocery } \\
\text { Store and Café }\end{array}$ & $\begin{array}{l}\text { Calvin and } \\
\text { Cathy }\end{array}$ & $\begin{array}{l}\text { Organic restaurant and } \\
\text { grocery store }\end{array}$ & Edmonton & 20 & $\begin{array}{l}\text { Male and } \\
\text { female }\end{array}$ & 7 \\
\hline Eastside Works & Mary & $\begin{array}{l}\text { Employment development } \\
\text { for homeless people }\end{array}$ & Vancouver & 3 to 15 & Female & 6 \\
\hline Fair Flowers & Laura & Florist & Vancouver & 1 & Female & 20 \\
\hline Get Organized & Jill & $\begin{array}{l}\text { Closet organizing } \\
\text { consulting }\end{array}$ & Vancouver & 1 & Female & 2 \\
\hline $\begin{array}{l}\text { Holistic } \\
\text { Consulting }\end{array}$ & Mike & $\begin{array}{l}\text { Holistic agricultural } \\
\text { management consulting }\end{array}$ & Edmonton & Sole proprietor & Male & 15 \\
\hline Humour Works & Chris & $\begin{array}{l}\text { Business consulting - } \\
\text { humour in the workplace }\end{array}$ & Vancouver & 4 & Female & 4 \\
\hline Market Earth & Roberta & $\begin{array}{l}\text { Household and personal } \\
\text { goods-retail }\end{array}$ & Edmonton & 5 to 6 & Female & 14 \\
\hline Mini-Cakes Inc & Kelly & Bakery & Vancouver & 15 & Female & 5 \\
\hline Name Domains & Pin Yin & $\begin{array}{l}\text { Register businesses on the } \\
\text { internet }\end{array}$ & Vancouver & 30 & Female & 7 \\
\hline New You & Ellen & Style consultancy & Vancouver & 1 & Female & 3 \\
\hline $\begin{array}{l}\text { North River } \\
\text { Associates }\end{array}$ & Patricia & $\begin{array}{l}\text { Obtain development } \\
\text { approvals for real estate } \\
\text { industry }\end{array}$ & Vancouver & 12 & Female & 18 \\
\hline $\begin{array}{l}\text { Northern } \\
\text { Network } \\
\text { Graphic Design }\end{array}$ & Wendy & $\begin{array}{l}\text { Graphic design and } \\
\text { illustration }\end{array}$ & Vancouver & Sole proprietor & Female & 1 \\
\hline $\begin{array}{l}\text { Ray Social } \\
\text { Responsibility } \\
\text { Consultancy } \\
\end{array}$ & Raymond & $\begin{array}{l}\text { CSR consultant for first } \\
\text { generation companies }\end{array}$ & Vancouver & Sole proprietor & Male & 3 \\
\hline $\begin{array}{l}\text { Respectful } \\
\text { Workplaces }\end{array}$ & Phyllis & $\begin{array}{l}\text { Conflict resolution for } \\
\text { businesses }\end{array}$ & Vancouver & $\begin{array}{l}\text { Proprietor \& } 1 \\
\text { business partner }\end{array}$ & Female & 17 \\
\hline $\begin{array}{l}\text { Restaurant } \\
\text { Organic }\end{array}$ & $\begin{array}{l}\text { Ron and } \\
\text { Wanda }\end{array}$ & $\begin{array}{l}\text { Organic and locally grown } \\
\text { restaurant }\end{array}$ & Edmonton & $\begin{array}{l}7 \text { to } 12 \\
\text { depending on } \\
\text { season }\end{array}$ & $\begin{array}{l}\text { Male and } \\
\text { female }\end{array}$ & 10 \\
\hline Stellar Trophies & Bill & Award manufacturing & Vancouver & 11 & Male & 7 \\
\hline $\begin{array}{l}\text { Steward } \\
\text { Consulting }\end{array}$ & Leslie & $\begin{array}{l}\text { Marketing and } \\
\text { communications } \\
\text { consultancy }\end{array}$ & Edmonton & Sole proprietor & Female & 6 \\
\hline $\begin{array}{l}\text { Sustainable } \\
\text { Consulting }\end{array}$ & Sally & $\begin{array}{l}\text { Social auditing and } \\
\text { consulting }\end{array}$ & Vancouver & Sole proprietor & Female & 10 \\
\hline Workabilities & Dumont & $\begin{array}{l}\text { Design for accessible } \\
\text { workplaces }\end{array}$ & Vancouver & 2 & Male & 3 \\
\hline Write On & Sandy & Business writing services & Vancouver & 1 & Female & 2 \\
\hline
\end{tabular}




\section{Findings: Community, Moral Ambiguity, and Perceptions of Social Responsibility}

As this research project was founded on collaborative action learning, we were interested in identifying the common ground among the participants. One group in particular decided to develop a declaration of their SR beliefs by collaboratively writing a pamphlet for use customers or clients, necessitating the deliberate building of consensus, and reflected in the value statements articulated in their discussions. The first section of findings identifies areas where there was a high degree of commonality. However, throughout the discussions, it was apparent that there were significant divergences partly due to type of business as well as to different understandings and SR practices represented in the second section. The third section of findings elaborates their insights and discussions by mapping the spectrum of practices as described by the participants and categorized by the researchers.

\section{Morality as Community Relationship and Well-being}

Consonant with the findings of Vitell et al (2000) and Jenkins (2006) regarding SMEs, our study also confirmed that the business reflected the personalized style and values of the "ownermanager." In particular, the practice of social responsibility directly reflected the interpretations of social responsibility held by the owner-manager. Most often, the business operations were established to publicly exhibit the personal moral philosophy held by the owners, in this case, for social responsibility.

The thing is that you hope that you can influence people because you're practicing something different... because we are built on philosophy. [Wanda, Restaurant Organic, 11. 649-669] People have to start eating consciously or eating with a conscience so that they know why they're eating a specific thing or buying a specific thing or why they shouldn't buy. So many people, we go into a grocery store...you're not thinking about why or where it came from, how it was raised... and I say... we have to buy consciously, not unconsciously. [Ron, Restaurant Organic, 11. 270-275] ${ }^{1}$

Moreover, these small business owner-managers judged their sense of social responsibility by the willingness to maintain their commitment to the philosophy, even in challenging times.

It's keeping your commitment no matter what. When times get tough we stayed, we stayed the course...I mean we just stayed with the principle and figured...we make [it] this way, [or] we don't make it at all. We're not going to compromise what we believe in. [Ron, Restaurant Organic, 11.2409-2413]

The first two years we were not making money at all and there were many, many nights where we thought, 'Should we continue? Is it worth it? Should we just go all conventional?'... we didn't do it because we had so much heart into what we're doing. [Cathy, Earth's Grocery Store, 11. 827-830]

Not only was it expected that they would adhere to the commitment at all times but that their philosophy permeated all parts of the business operation. The second research group expressed this as "principle two" in their pamphlet. "We value "whole business" that benefits local people, the environment and the community" [Research Group 2, 2006]. Social responsibility constituted a working philosophy for these owner-managers and was defined as social and environmental

\footnotetext{
${ }^{1}$ Transcript excerpts from individual interviews are presented with pseudonyms for names of the owner and business, and line numbers. Excerpts from group interviews show the transcript number and line numbers.
} 
well-being. Many participants continuously evaluated themselves against the principles they considered to comprise social responsibility, to determine how well these principles were integrated throughout all aspects of the operation, and whether they had compromised their commitments in any way over the long haul. This required a high degree of ongoing reflexivity which was exemplified throughout their conversations.

While nuanced in expression across the participants, the most significant factor that shaped the understanding of community was commonly understood as local, geographic community, lived out in face-to-face relationships [10-01, 11. 2028-2031]. Owners considered their key stakeholders to be all the direct, personal relationships they had with customers, suppliers, employees, or community contacts, with whom they had built a sense of trust and to whom they felt a sense of accountability [06-01, 11. 981-993]. Most relationships in small business operate upon personal engagement, therefore their ethics were similar to personal systems of morality, described as trust, honesty, fairness, respect, and community service. In this way, a personal style of morality became translated into socially responsible business ethics, one facet of which was characterized as transparency: "We value openness and make ourselves accessible to customer feedback and questions. This is an ongoing conversation....We will be willing to engage in a conversation and to explain our practices" [Research Group 2, 2006].

Most participants claimed to want their operation to be transparent and directly accountable to stakeholders. Not only was strength of commitment and public evidence of accountability important to their sense of social responsibility, but their business operation gave priority to community values as much as to profits: "We know we could make more money if we did things differently, but that's not why we started in this business...that's not who we are" [Ron, Restaurant Organic, 11.2409-2413]. Principle 10 from the group pamphlet explains this position further:

We believe in being a values-based company.

Therefore, we weigh social and environmental values equally with financial success. We believe small businesses such as ours play an important role in creating a fairer, more democratic, and environmentally respectful future for our communities... [Research Group 2, 2006]

One participant summarized, "No business is sustainable if it is not socially responsible" [06-01, 11.20]. As found in other studies (Jenkins, 2006), this term sustainability was used interchangeably with social responsibility. While there was considerable debate about the meaning and utility of the term 'sustainability', it was, for these small business owners, primarily grounded in responsibility to community: sustainability "revolves around relationships and interactions," more specifically as "care of people and care of the planet" [06-01,11. 580]. The sixth principle developed by group two emphasized this:

We believe that business is relationships.

Therefore, we have created a business that builds trust and respect as the foundation for good relationships between us and customers, employees, and suppliers. We practice workplace democracy where employees benefit, and can seek a sense of fulfillment by their work with us .... We believe small business has a unique role in building community. [Research Group 2, 2006]

Therefore they highlighted both social and environmental responsibility in a way that also anticipated a new arrangement of community relations. Many participants envisioned the role of business as contributing to a moral vision of working and living that considered the common 
good distinct from the good of shareholder through profits or other self-interested stakeholders: "the primary um driving factor isn't that it's called business; it's about a way of living, a way of living and working together" [Roberta, Market Earth, 11. 308-316].

We strive to be responsible stewards of the common good.

We take time to understand the gifts we have been given, take responsibility to use these gifts wisely in the world to do what is right and honorable. We recognize our actions represent our awareness of our social and environmental connectedness. [Research Group 2, 2006]

This new way of living and working was predicated upon a new way of thinking about themselves as part of a web of social and environmental connections. Some participants described this as connectiveness thinking, suggesting that urban people in particular lose touch with this connectiveness and ecosystem dependence, as they simply press a button for electricity or move a handle for water [06-01; 11. 1371-1383]. Specifically, owner-managers said they contributed to the common good by participating in community events, helping to solve community challenges, trying to reduce their impact on the local environment, and hiring staff from the immediate community where possible. Their community involvement ranged from philanthropy (donating a percentage of profit to community initiatives) to more active participation such as volunteering for local agency boards and offering store space to host public events such as films and speakers.

[W]e support the work individuals do within [other] organizations. ...because I'm thinking, 'every day what do we do?' We help people do whatever work it is that they want to do in the community." [Roberta, Market Earth, 11. 518-522]

Indeed, one of group two's principles was "We believe in community involvement to build the fabric of strong, self-reliant communities" [Research Group 2, 2006]. However, when this conception of social responsibility was questioned at a deeper level in terms of practice, some ambiguities emerged.

Ambivalence as Community Change Agent

A key area of moral ambiguity was embedded in these small business owners' sense of themselves as change agents. All described themselves to varying degrees as agents working for social change: to bring about an alternate vision of society as well as of doing business. For some, these were radical visions of change:

I mean to make change right... are you going to be passive about it or do you want to be more assertive ... by being here we're stepping forward and we're saying you know, we have to change. Therefore you should be doing this. We're not asking you to do it. We're telling you to do it. Because we need to make a change. [Jana, Windsong Design, 11. 1500-1514]

Others viewed themselves as social leaders, standing apart from other firms:

Creating the social change...I think that's the essence, one of the essences anyway that makes us different from the corporate model because they're still using the dominant model. [Roberta, Market Earth, 11. 2020-2023]

Overall in their social change approach, these owner-managers tended to remain detached from others, concerned about their public reputation, and focused on local influence. While they 
aspired to change consumer behavior, participants said they often were cautious when encountering customers' conservative preferences, such as when one consultant accepted that his client was uninterested in selecting "responsible" off-shore suppliers (e.g. with humane work conditions).

While these owner-managers were often frustrated by insufficient recognition and tax incentives by governments for small business adoption of CSR practices, none viewed part of their role as attempting to influence government policy. In fact advocacy or activism was viewed by participants as problematic. Some were concerned about being viewed as left-wing, thereby losing credibility as business owners:

When we opened in 1997 we were more assertive in...that we were going to be organic, we were going to be healthy, we were going to be nutritious...And we put it all over the menu and...we were right into their faces, evangelizing the whole thing like fundamentalists... And what it did is it backfired. People stopped coming...Y You know they started talking about it, gossiping about the vegetarian freaks and gay chefs, they thought it was just wacko!" [Ron, Organic Restaurant, 0906-09, 11. 303-327]

Resistance to dominant norms through activism was described as 'judgmental' or 'negative'. Rather, they were concerned about being positive role models by manifesting the changes they wanted to see rather than criticizing what they do not see.

Most participants described their evolution from being an advocate toward the position of educating others about social responsibility. In trying to attract and keep clientele, they did not want to be seen as "cultish, hippies, out there, judgmental or confrontational." Experiencing patron loss when labelling their practices a certain way they preferred to model desirable practices as a form of education and to educate about chosen products and services when asked. All business owners emphasized their focus on relationships, supporting customers interested in social responsibility:

We support...individuals in their own personal choices and changes. [Roberta, Market Earth, 0906-02, 11. 522]

Many owners focused on the local, preferring to work face-to-face with customers, rather than through virtual environments, and establish community and personal relations of trust. However, this limited the geographic reach of the business and resulted in lower volumes and overall less demand. Even though they stipulated their deliberate intention to be social change, the overall possible effect was to constrain the owners' capacity to effect social change that for some, formed an important aspect of their business identity.

Most participants described their work in terms of effecting change one customer at a time rather than engaging in broad-based social change mechanisms. Thus, local interpersonal relationships were key to their view of SR practice:

A lot of small companies have very, very good relationships with their customers. It's different than just having a relationship. In fact we have discussed that very often. That role as a mentor, teacher, leader. [Roberta, Market Earth, 11-01, 11. 562-566]

They often discussed their role as educators but they often found the high level of expectations and vigorous challenges to their practices to be exhausting, once again stimulating a sense of 
ambivalence about boundaries in this relational way of doing business. The grocery store owners expressed shock when a customer rifled through their garbage cans to see if they were composting and recycling and then challenged them for not doing all they could [06-01, 11. 963993]. Another said:

You just have to let go some dreams ... you can live with limits ... the community can be the black hole that, it just swallows all your energy' [Alasie, Aputik Garments, 11.329$331]$.

While all of these business owners described themselves as working for and within a more communitarian, relational view of society than the competitive market system tended to allow, most did not view themselves as acting in coalition with other like-minded businesses or agencies to create social change. The exceptions were the awards manufacturer and the outfitter retail firm, both of which were the largest of the businesses, the longest surviving, and had the most developed CSR plans. The others expressed strong disinterest in forming alliances with institutions such as education or government, with labour groups, or with NGOs such as environmental groups or local community agencies to bring about change:

I wish the government would keep their nose out of it. Second of all...the government doesn't know anything about social responsibility or organics or agriculture. . . They're ill informed and they are uh corporate driven, they're not people driven. [Ron, Organic Restaurant, 11. 554-563]

They stated instead their preference to rely on themselves to create a vision of an alternate society, to generate the resources, and design the process to bring it about. Their connections were largely limited to their customers. However, many owner-managers perceived themselves as connected to larger social movements by providing learning space for the public as part of their private space, whether through displays of information, meeting space, networking of community members, or hosting educational events.

Naturally to survive, small business owners walked a careful line in exhibiting their social change intentions. This gave evidence of a conflict between an identity as change agents and their actual behaviors. While many perceived themselves as participating in a collective movement for change, they remained rather isolated as individual agents, acting cautiously and conservatively. They considered their contribution to social change to be their existence as role models rather than activists. However, as they discussed their role as small business, in contrast to medium-sized business or large corporations, they were careful to differentiate themselves, revealing a spectrum of positions on SR.

\section{Mapping Perceptions and Positions within Social Responsibility}

As Jenkins (2006) found, these business owners indicated a lack of language to articulate their activities and a business model that represented their intentions. Most participants said they disliked the term "corporate" in corporate social responsibility: it held connotations of "big business" that was removed from the community and the relational realities of sole ownermanagers [06-01, 11. 294-300].

I suspect that [at] some point in time we will stop using the word 'corporate' ... because what we're talking about is about people and it's about human relationships and it's about community. [06-01, 11. 308-310] 
Further, many indicated a belief that "corporations" are largely working according to "models from the past" and are using the CSR label as an "add-on" rather than the raison d'etre of their business practice [06-01, 11. 336]. Some regarded corporate-level social responsibility as a cover for practices and a system that were inherently dysfunctional and unsustainable. Most believed that their business practices represented a fundamental change in core value assumptions.

...what do we need in our lives, what do we need to have fulfilling lives? I've never seen this [in a] business model...have I ever seen the question "what condition does our resource base have to be in indefinitely in order to sustain the production that we're going to do in order to make the people happy'? [06-01, 11. 463-481]

Yet in describing alternate business models and their moral underpinnings, these owners distanced themselves from hard-line ideological and moral positions. They preferred a more pragmatic description of their own value-based approach, that was fluid and even eclectic.

... there's this list that either you're a hardest capitalist or you're a softest socialist and...there's no understanding that you can, well, why can't you just be as a business and [as] a political perspective, socially responsible and sustainable? [06-01, 11. 381-385]

Yet however eclectic their position, some were clear about their radical shift to a fundamentally different concept of the role of business within community:

In, you know, the corporate world now... a lot of them are truly struggling trying to be more ecologically and socially responsible... but because they're trying to do [it]...within the current framework they're trying to make adjustments; it's the framework [itself] that doesn't work...that's why they're having so many problems is that they [are] trying to have business as usual but a little bit differently...it doesn't work [06-01, 11. 415-446]

Most described their own motivation for SR to be internal and premised on their value system. Corporate-level SR, for them, was simply a pragmatic or even manipulative response to customer demand, not because of an intrinsic belief in SR necessarily, but because "the customers want it, so they'll do it because it affects their bottom line...they'll be socially responsible as long as they can make money, you know [06-01, 11. 581-582, 629-630, 650]. For these small business owners, this external motivation was less acceptable.

Thus in articulating their own moral vision and comparing these to what they perceived to be corporate-style SR, these small business owners focus on three elements: the motivation behind adoption of SR practices, the extent to which SR practice was integrated into core operations (business purpose, product sourcing, waste practices, employee relations, etc.), and the relation of CSR to profit. From the descriptions of their understanding and practices, the following spectrum of positions emerged. We have characterized these positions as ranging from "weak" to "strong" social responsibility to capture the ways participants seemed to view these positions.

$\begin{array}{cccc}\text { Weak (within traditional capitalism) } & \text { (new economic framework) Strong } \\ \text { Corporate } & \text { Corporate } & \text { Entrepreneurial } & \text { Community } \\ \text { Greenwashing } & \text { Triple } & \text { Social } & \text { Transformation } \\ \text { Approach } & \text { Bottomline } & \text { Responsibility } & \text { Approach } \\ & \text { Approach } & \text { Approach } & \end{array}$


Participants described a weak SR position pejoratively as "corporate greenwashing" where profit maximization remained the central motivation but was camouflaged by a public relations exercise that marketed their corporation as socially and environmentally responsible. They considered this to be greenwashing because minor modifications in the product, the manufacturing process, or the service were amplified out of proportion to its real impact in terms of social and environmental responsibility.

They described a slightly stronger version of social responsibility to be a corporate "triple bottomline" approach. This is the attempt of a large corporation to transition toward triple bottomline goals (the equivalence of social, environmental and fiscal goals) as part of a larger vision of social responsibility and an authentic commitment to manifest this in their business practices. However, they noted that large corporations, have a fundamental barrier by virtue of their size, bureaucratic nature, and stakeholder/stockholder interests but also because they are operating within traditional capitalism. This makes an authentic transformation from conventional business toward social responsible business difficult despite the commitment of leaders or champions in the organization. They suggested that sheer size dictates against a company being relationally based - an aspect they considered a core element of social responsibility.

An even stronger version of social responsibility is what they described as "entrepreneurial" social responsibility. They described these practitioners as enterprising small business people who see a niche for a product or service that is socially responsible in its inception, but this innovation is not necessarily part of a larger social vision. The businessperson does not question market principles but works within the dominant economic system in generating profits and using them to remain viable. While they may do "good things" in terms of community and environmental altruism, they do so within the entrepreneurial spirit of individual success and autonomy rather than as part of a social change mandate.

The strongest version of social responsibility is what they described as a "community transformation" approach in which the small business owners feel a significant tension with the market system and establish their business as part of a larger social vision of building a different economic and social reality. Rather than just manifesting social responsibility in their business practices, they also expressed the onus of an educative role to create demand for socially responsible goods and services. Thus, they not only responded to the rising public demand for socially responsible goods and services, they also articulated a need to create this demand. They expressed tension with market principles and the demands of business viability as well as tension with their customers/clients with whom they often debated SR best practices. This is where many participants positioned themselves. In the statement of principles formulated collaboratively by group 2, this position is clearly visible:

We believe in a fair and environmentally respectful society.

Therefore we have created business that will contribute to building this kind of society. We believe that this kind of society is possible. .... We will act as leaders; leading by example. We are positioned to offer opportunities for change and will consciously lead toward this vision.

We value fairness.

Therefore, we charge fair prices; pay livable wages; take only a fair return from the 
business. We will discuss and make intentional decisions regarding the distribution of the wealth and benefits from the business.

We believe in creating positive social change.

Therefore we innovate to create a ripple effect toward positive social change. We consider the impact of our actions on present and future generations. [Research Group 2, 2006]

Despite this agreement, there was also a range of perspectives within this approach. One participant considered the decision to write a pamphlet as "soft."

[Social responsibility] is about personal relationships, people [in the group] were reluctant to do something that would require like more risk to themselves and/or because they're so accustomed to making very personal choices . . . . that unless someone had...their own signature way of doing things it was just something they weren't interested in. [Roberta, Market Earth, 0906-02, 11. 903-909]

What they did not discuss were the business participants who worked within co-operatives, a model aligned with old ideological models. Co-operatives exemplify democratic socialist values through a collective ownership and decision-making structure. In fact, this was one area of significant tension where many of the owner-managers in this study, wanting to protect their freedom to enact their moral vision, did not want to function like a NGO (non-government organization) and did not want to be beholden to employees. This autonomy and control over the operation was the central reason they chose to be business owners rather than part of a NGO. Many appeared to be risk-takers who desired self-sufficiency and the freedom to innovate based on principles of social responsibility.

They also avoided the ideological implications by framing their messages to customers in more neutral ways "to start where the customers are" [10-01; 11. 1814]. Yet, they also acknowledged their socialization into orthodox business practices. One participant noted the inherent contradiction of wanting to network and share ideas with other like-minded businesses but also wanting to protect proprietary information. Finally, the dialogue itself made other participants question their non-politicization about economics and business.

I wonder sometimes if the scale of challenges we face is such that I need to get out of my comfort zone and be more radical. . . but I might start feeling [it] is necessary is to be more active politically. If, because all of this sort of voluntary corporate stuff is not achieving results at the speed at which we, we need it to and there are things that are going rapidly downhill the other way. [Sally, Sustainable Consulting, 11. 1245-1256]

Most participants described themselves as leaders and innovators "creating the future" and they discussed the tensions of trying to do so within existing economic structures

\section{Analysis and Discussion: Capitalism, Social Responsibility and Ethics}

Is it possible for capitalism to be socially and environmentally responsible? In an ethical analysis, orthodox capitalism is built upon universal ethical egoism comprised of basic premises operational in day-to-day business. The first is that it is ethically necessary to act in one's selfinterest. Many ethicians concur that it is questionable whether this is good moral theory for, as commonly agreed, "morality is about overcoming our selfishness and living our lives with a positive concern for the well-being of other people for their own sake" (Hinman, 1994: 137). The 
maximizing version of ethical egoism is that everyone should try to maximize self-interest, which can lead, at best, to a kind of pragmatism and at worst, a ruthlessness that permits various kinds of behaviour such as cheating, lying, and exploitation, as long as the larger goal is being met (Hinman, 1994: 139). The second assumption is that consumers operate on the basis of hedonistic egoism in that they try to maximize their pleasure in the short-term, rather than using rational egoism that considers long-term ends. In applying ethical egoism to business, Hinman explains, a business owner located in a neighbourhood where there are repeat patrons would tend to operate on long-term egoistic interests rather than a business with few repeat customers or not located solely in the neighbourhood.

Corporate-based SR, it can be argued, issues from a different ethical base, that of utilitarianism. In this ethical view, consequences count. The morality of an action is judged solely by the consequences, favoring that which produces the greatest overall positive outcomes for the majority (Hinman, 1994). In this case, corporate-level social responsibility is important as it the considers long-term social and environmental impacts, not necessarily considered previously. However, as the participants debated, is ascertaining the consequences good enough criteria for a strong practice of social responsibility?

The participants in this study appeared to be operating largely from two other ethical premises Kantian ethics and virtue ethics - which explain their suspicions of CSR and their moral commitments to community. As they expressed, what matters about the practice of SR is the motivation behind it. In particular, they repeatedly stated that they carry out SR because it is the right thing to do and they gave various examples where they would choose not to engage in a practice or sell a product if it contravened that sense of what was right. Kant calls this the ethics of duty whereby the moral worth of an act depends upon the reason for doing it, outside of any self-serving motive. Kant does not consider feelings of compassion or care as motivators but rather the rational determination a person engages in to choose the morally superior action.

Again in the same way the huge connectiveness... [decisions] have a way of moving out and affecting all of society ultimately... recognizing that you know it's not just about you, it's not just about...you making a living, it's about how does this affects, you know, the community in which I live, the world in which I [live]. [06-01, 11. 275-280]

These small business owners considered the impact of their actions as emanating from a relational worldview. The other fundamental element of Kantian ethics is respect, where people are never considered means to an end but ends-in-themselves, but with inherent human dignity. This view was present throughout most of the participant discussions about stakeholders and their right to a differing opinion or their need for access to good information for their moral agency. Some participants went even further to stipulate that it was the character of the business owner that was being publicly reflected within their business practices. Thus, it was not only about motivation, but about the virtues of the owner-manager that is vital to SR.

This is similar to Aristotle's argument that ethics is not only about the principles but also about the persons, their desire to do the good, and their good judgment in carrying that out (Hinman, 1994). These owner-managers indicated that they wanted the stakeholders to judge their business not by an accountability report but by their level of reflectiveness about what is fair and responsible in all aspects of their business [11-01, 11. 1747, 1918-1929]. In this way, their moral 
position is rooted in both rational decisions about what constitutes the good and emotional desire for a better world. As described earlier, these participants started from questions about what is good for individual happiness and fulfillment but more importantly what is good for the common life. Thus, the current discourse about social responsibility reflects this interplay of different ethical systems that are simultaneously operative in contemporary society. The view of SR by these small business owners, the ambiguities they experience in their practice of SR, and their suspicions of CSR may be viewed as reflecting certain fragmented ethical perspectives operative in larger society.

When examining some of the ambiguities and paradoxes that the participants revealed, it could be argued that despite their commitment to social responsibility and building community, these small business owners were reluctant to work cooperatively. They spoke about social responsibility as an individual responsibility. They pragmatically restricted their engagement in ideological debate or social activism to retain business credibility with a wide range of customers. However they represented themselves, in different ways, as connected to a web of relations. They referred to themselves as innovators practicing unique value premises that can ripple outward into society. This is becoming known in ethics as holism, where one acts with awareness of multiple interdependent relations as in an ecosystem (Macrae, 2003). One participant, for example, explained that the process of creating sustainable communities and changing people's attitudes around sustainability can take years, and that others often believe existing structures are too large and rigid to change:

So what you do is you stand alone and you say OK I'll do what I'm going to do and then you start affecting the people around you and they buy in one at a time and in return influence one at a time, right, it complements. [Ron, Restaurant Organic, 11-01, 11. 210223]

In this moral vision, change does not occur through conflict or confrontation but through small individual actions that can attract support and plant seeds of transformation. As one participant phrased it:

It's attraction not promotion...presenting opportunities...if you go around preaching to people, they're not going to hear it...[its] leading by example. (11-01, 11. 173, 242, 195196, 181].

In their different ways, these business owners clearly expressed moral commitment to bring about a different reality. As they described, it was through the interchange with local customers or clients primarily that they enacted this commitment:

From a customer...two kinds of examples, one kind of example, you go 'oh, that's a good idea' and we learn from it. And the other kind, you're going, 'Holy cow, what? We are trying our best here' that's a kind of, sort of pie in the sky...that keeps us on our toes in a different way. [Calvin \& Cathy, Earth's Grocery Store and Café, 06-01, 11. 958-961, 989-990]

In the beginning I was not, I really didn't feel it was our store, it feels [like] everyone, like a team store.... [Roberta, Market Earth, 06-01, 11. 1014-1016]

These small business owners perceived themselves as being on the cutting edge of SR practices, but distinct in their moral position and approach from other organizations declaring allegiance to 
social responsibility: corporations, not-for-profit groups, and government departments. While the small businesses expressed overriding commitment to building and transforming community, they were ultimately cautious about coordinating their efforts with these other organizations.

Overall, small businesses practicing social responsibility walk a fine line as they balance the demands of sustaining their enterprise in highly competitive conditions while attempting to enact deeply felt value principles with consistency and integrity. These value principles are developed personally by the small business owner and are often closely linked to the core purpose of the business, even to the motives for business start-up. Their sense of a moral position in social responsibility practice appears linked to three main elements: one's motives for practicing SR, the extent of integration of SR practice into core business operations, and the relation of SR activity to the enterprise's profit. Ethical conflict arose for them personally within these three areas. Thus while most viewed themselves as operating from a distinct and intentional moral position, most experienced some tension in the everyday enactment of this position. Many talked in terms of interconnection and working through relationship, but preferred to restrict this to local relations, with customers for example, that they could control to some extent. And although most articulated a vision for social change, they were pragmatic in remaining distant from radical activity and ideological pronouncements. Most preferred to work by seeding ideas and modeling their values rather than by explicitly leading efforts for social or economic transformation. All preferred to work autonomously rather than through networks of other organizations in the private and or public sector.

However, one theme above all cut through the many different meanings, priorities in practice, and moral positions of social responsibility described by these small business owners: a moral commitment to local community. This commitment was evident in both their descriptions of priority, their statements of belief, their assessment of the spectrum of SR practices and it tended to envelop additional priorities such as conserving the natural environment. In their particular emphasis on community as a web, synonymous with sustainability, a fundamentally relational worldview was apparent in which these small business owners viewed their moral responsibility as influencing those around them in small ways that could ripple into larger social change over the long term.

\section{References}

Canadian Business for Social Responsibility (CBSR), (2001), Government and Corporate Social Responsibility: An Overview of Selected Canadian, European and International Practices, Canadian Business for Social Responsibility, Vancouver, BC, Available at www.cbsr.ca

Coelho, P.R.P., McClure, J.E. \& Spry, J.A., (2003), “The social responsibility of corporate management: a classical critique", Mid-American Journal of Business Vol 18, pp. 15-24.

Conference Board of Canada (2004), The National Corporate Social Responsibility Report: Managing Risks, Leveraging Opportunities, Conference Board of Canada. Available at http://www.conferenceboard.ca/documents.asp?rnext=734

Crowther, D. and Rayman-Bacchus. L., (2004) Perspectives on Corporate Social Responsibility, Ashgate, Aldershot, UK. 
Davidson, D.J. and Hatt, K.C., (2005), Consuming Sustainability: Critical Social Analyses of Ecological Change, Fernwood, Winnipeg, Canada.

Dobbin, M., (1998), The Myth of the Good Corporate Citizen: Democracy Under the Rule of Big Business, Stoddart, Toronto.

Co-author. (2002a)

Co-author. (2002b)

Feldman, A., (1999). "The role of conversation in collaborative action research:, Educational Action Research, Vol. 7, No. 1, pp. 125-144.

Hinkley, R. C., (2002), "How corporate law inhibits social responsibility”, Humanist Vol 62, pp. 26-28.

Hemingway, C. A. and Maclagan, P.W., (2004), "Managers' personal values as drivers of corporate social responsibility", Journal of Business Ethics Vol. 50, pp. 33-44.

Hinman, L., (1994), Ethics: A Pluralistic Approach to Moral Theory, Harcourt Brace College Publishers, Orlando, FL.

Hopkins, M., (2003), The Planetary Bargain: Corporate Social Responsibility Matters, Earthscan, London, UK, Sterling, VA.

Husted, B. W. and de Jesus Salazar, J., (2006) "Taking Friedman seriously: maximizing profits and social performance", Journal of Management Studies, Vol. 43, pp. 75-91.

Jenkins, H., (2006), "Small business champions for corporate social responsibility", Journal of Business Ethics Vol. 67 No. 3, pp. 241-256.

Joyner, B.E. and Payne, D., (2002), "Evolution and implementation: a study of values, business ethics and corporate social responsibility", Journal of Business Ethics Vol. 41, pp. 297311.

Kell, G., (2003), “The Global Compact: Origins, Operations, Progress, Challenge”, Journal of Corporate Citizenship, Vol. 11, pp. 35-49.

Kember, D., (2000), Action Learning, Action Research, Kogan Page, London, UK.

Kemmis, S. and McTaggart, R. (2000). "Participatory action research," in Denzin N K. and Lincoln Y. S. eds., Handbook of Qualitative Research, second edition, Sage, Thousand Oaks, CA, pp. 567-606.

King, R., (2002), Globalisation, Corporate Social Responsibility and Sustainable Development, (Centre for Sustainable \& Environmental Management, London).

Lepoutre, J. and Heene, A., (2006), "Investigating the Impact of Firm Size on Small Business Social Responsibility: A Critical Review”, Journal of Business Ethics Vol. 67, No. 3, pp. 257-273.

L'Etang, J., (1995), "Ethical Corporate Social Responsibility: A Framework for Managers", Journal of Business Ethics, Vol. 14, pp. 125 - 132.

Lincoln, N. K. \& Guba, E. G., (2000), "Paradigmatic Controversies, Contradictions and Emerging Confluences, in Denzin N. K. and Lincoln, Y. S. eds., Handbook of Qualitative Research, second edition, Sage, Thousand Oaks, CA, pp. 163-188. 
Macrae, S. (2003), An Introduction to Ethics: Theories, Perspectives, and Issues. Pearson Education Canada, Toronto. ON.

McGill, I. \& Beaty, L., (1995), Action Learning, Kogan Page, London, UK.

McWilliams, A., Siegel, D.S., and Wright, P.M., (2006), "Corporate Social Responsibility: Strategic Implications”, Journal of Management Studies, Vol. 43, No. 1, pp.1-18.

Perrini, F., Russo, A. and Tencati1, A., (2007), "CSR Strategies of SMEs and Large Firms: Evidence from Italy", Journal of Business Ethics, Online first. Available at http://www.springerlink.com/content/p2538114623003r2/?p=1f004d2f5f27429c9e88

Research Group 2, (2006), Principles of Social Responsibility, unpublished pamphlet, University of Alberta, Edmonton, AB.

Revans, R. W., (1995), The ABC of Action Learning: A Review of 25 years' Experience. University of Salford, Salford, England.

Seifert, B., Morris, S. A. \& Bartkus, B. R., (2003), "Comparing Big Givers and Small Givers: Financial Correlates of Corporate Philanthropy", Journal of Business Ethics, Vol. 45, No. 3, pp.195-211.

Vitell, S. J., Dickerson, E. B. and Festervand, T. A.: 2000, "Ethical Problems, Conflicts and Beliefs of Small Business Professionals", Journal of Business Ethics, Vol. 28, No.1, pp.1524.

Whitehouse, L., (2006), "Corporate Social Responsibility: Views from the Frontline", Journal of Business Ethics, Vol. 63, pp. 279-296. 


\section{Author Biographies}

Elizabeth A. Lange is Assistant Professor, Educational Policy Studies, at the University of Alberta, Canada. Her research focuses on transformative and restorative learning in adult education, sustainability education related to lifestyle and societal change, and learning processes for catalyzing citizenship participation and social/environmental responsibility.

Tara F. Fenwick is Professor and Head of Educational Studies Department at the University of British Columbia in Vancouver, Canada. Her research focuses on learning processes and knowledge generation in work environments, with particular interest in knowledge workers, the effects of globalizing processes on work and learning, and knowledge of vulnerable workers. 